\title{
EFFECT OF JOB SATISFACTION ON TURNOVER INTENTION AND \\ ORGANIZATIONAL COMMITMENT AS MODERATOR VARIABLE AT MULTI JAYA LOMBOK
}

\author{
NADIA HASAN \\ Student of Postgraduate, \\ Faculty of Economic and Bussiness, University of Mataram
}

ABDUL AZIZ BAGIS

Lecturer of Postgraduate, Faculty of Economic and Bussiness, University of Mataram

SRI WAHYULINA

Lecturer of Postgraduate, Faculty of Economic and Bussiness, University of Mataram

DOI: 10.31364/SCIRJ/v7.i10.2019.P1019716

http://dx.doi.org/10.31364/SCIRJ/v7.i10.2019.P1019716

\begin{abstract}
The purpose of this study includes: (1) To analyze the effect of job satisfaction on employee turnover intention on Multi Jaya Lombok. (2)To analyze the normative commitment to strengthen the influence of job satisfaction on employee turnover intention on Multi Jaya Lombok. types of research used in this research are causal. The population of this research is all employees some 115 people. Data collection tools that will be used is the questionnaire. Data analysis techniques used in analyzing the influence of the independent variable on the dependent variable are moderating regression analysis (MRA). Based on data analysis and discussion that has been done, it can be concluded that: (1) Directly, job satisfaction has a significant influence on Turnover Intention. (2) Commitments Employee Job Satisfaction can strengthen the influence of Turnover Intention.
\end{abstract}

Keywords: Job satisfaction, Commitment, Turnover Intention.

\section{BACKGROUND}

One aspect that is important in an organization is the Man who is in it. Humans always active and dominant roles in every organization, because people become planners, perpetrators and decisive achievement of organizational goals. The organization's goals can not be achieved without human role. Issues of human resources that often arise and hinder the performance of companies that are turnovers. The desire to move (turnover intention) is a signal of the beginning of the turnover of employees in the organization. turnover intention is the degree of inclination attitude held by employees to find new jobs elsewhere or their plans to leave the company within three months of the coming six months to come,

Increased labor displacement can reduce profits and affect the efficiency of the overall business. With the high rate of turnover that occurs in the company will increasingly pose a variety of potential costs of both the cost of training that has been invested to the employee, who must be sacrificed the level of performance, time and cost of recruitment and retraining (Kelvin and Indrianto, 1999: 2).

According to Dalton and Todor (1993) in Rival (2001: 335-352) provide the support that: "The negative impact of job displacement is on quality and the ability to replace (replaceability) individuals who leave or out of the organization". High levels of employment displacement would cause a negative impact on the organization, such as the instability of the labor conditions and increased human resource costs. It makes the organization is not effective because the company losing experienced employees and the need to retrain new employees as a country that scores a hit economic growth which increased demand for skilled workers, Indonesia is also not free from this phenomenon. 
Global Strategic Rewards Survey 2007/2008 conducted by Watson Wyatt found that generally employees or individuals working boldly decided to move because there are alternative jobs available in large quantities, so there is no difficulty for employees who resign to get his job back. Conditions in the country of Indonesia are not so, the unemployment rate inversely proportional to the jobs available. However, although the jobs available are very limited, the fact that there would indicate a high turnover rate in Indonesia. The level of turnover that occurred in Indonesia for key positions (managerial level and above) generally ranges from $10-12 \%$ per year.

Their employee's intention to leave the job in the organization can be caused by dissatisfaction in the worker (Mobley et al in Sunyoto, 2001: 365-366). Employee dissatisfaction can be expressed in a number of ways (Robbins and Judge, 2008: 107), among others such as "Exit (exit), the behavior that is intended to leave the organization, including the search for a new position and resigned and will enhance its levels of labor turnover (turnover ) ". According to Robbins and Judge (2008: 107) defines job satisfaction as a positive feeling about the work of someone who is the result of a evaluate characteristics. While Davis in Mangkunagara (2011: 117) Job Satisfaction interpret as support and do not support the feeling experienced by employees at work. While the sense of job satisfaction according to Mangkunagara is a feeling of self-supporting and not supporting employees associated with work and with her condition. Handoko (2011: 193) also interpret Job Satisfaction as a pleasant emotional state with which employees view their job. Factors that determine job satisfaction is the nature of work, supervision, pay at present, promotion opportunities, and relationships with co-workers. (Robbins and Judge, 2008: 107). Factors that determine job satisfaction is the nature of work, supervision, pay at present, promotion opportunities, and relationships with co-workers. (Robbins and Judge, 2008: 107). Factors that determine job satisfaction is the nature of work, supervision, pay at present, promotion opportunities, and relationships with co-workers. (Robbins and Judge,2008:107).

The role of the commitment may mediate the effect of job satisfaction in reducing the rate of turnover. The results of the Abouraia and Othman (2017) found that organizational commitment mediates the effect of intentions can get out of the employee. In addition, the results otherwise from Wahdaniah and Maryati (2016) that organizational commitment can not be a mediation influence job satisfaction support to turnover intention.

According to Yulianto Steer and Porter (2001:56-57) organizational commitment is obtained from a variety of different sources, among others: (1) The commitment of organizations affected by the work itself. (2) The commitment of organizations affected by factors related to the working environment including good relations with supervisors and the atmosphere of trust between employees and employers.
The higher the level of responsibility and autonomy associated with the job, the less repetitive, and the more interesting the work will be the higher the degree of commitment shown by the individual. In addition, the smaller the chance of promotion and the greater intension and ambiguities associated with the work, the lower the level of commitment that exists. According to the Munandar (2001:366-367) argues that: job satisfaction on employee workforce may be expressed into a wide variety of ways, for example, in addition to leaving a job, the employee can complain, defiant, steal from the organization, avoiding most of their job responsibilities.

According to Sri (2002:199-216) argues that: "An organization's commitment indicates a power of a person to identify his involvement in a part of the organization". Therefore, the commitment of the organization will create a sense of belonging (sense of belonging) to the workers of the organization. demonstrated commitment bonding which leads to a broader purpose, in this case, the purpose of the organization. According to Steer in Yulianto (2001: 101) argues that: "The commitment is an event where people are very interested in the goals, values, and goals of their employers".

While Mathiew and Zajak in Yulianto (2001: 35), states that: "With high employee commitment, the company will have positive impacts such as increased productivity, work quality, job satisfaction, and reduced levels of delays, absenteeism and turnover". Job satisfaction is very important because it accounts for the success of the organization, among others, can increase productivity with quality products and services, and also can reduce the level of absenteeism.

This time employee Multi Jaya Lombok is dominated by temporary staff (contract employees) with consideration of the salary they pay less when compared with permanent employees, it is easier to control to regulate working hours in accordance with needs companies, particularly in relation to doing the project wherein case of payment-related issues with their wishes can issue the employee unilaterally without notice to employees of the contract.

Conditions in Multi Jaya Lombok many transfers occurs due to a lack of commitment to the employee. Giving the task is often done by the employer by way of urgent and must be resolved, otherwise the jobs tend to be away on a motorbike to several projects of relatively short working time make them less happy and committed work. In addition, many project owners emphasize relatively fast time for completion of the work. Based on the above description of the background, the researchers intend to conduct a study more deeply on "Organizational Commitment Low Job Satisfaction In Effect Against Turnover Intention InMulti Jaya Lombok"

The purpose of this study include:

1) To analyze the effect of job satisfaction on employee turnover intention on Multi Jaya Lombok. 
2) To analyze the normative commitment to strengthen the influence of job satisfaction on employee turnover intention on Multi Jaya Lombok.

\section{LITERATURE REVIEW}

According to Robbins and Judge (2008: 107) defines job satisfaction as a positive feeling about the work of someone who is the result of an evaluation of its characteristics. Organizational commitment is (1) a strong desire to be a member of a particular organization, (2) the desire to try hard in accordance with the wishes of the organization, (3) confidence and acceptance of certain values and goals of the organization. In other words show that organism members expressed concern about the organization and its success and continuous progress (Lutahan, 2005).

Organizational commitment is defined as the climate, the atmosphere, the situation where employees are in favor of a particular organization as well as the objectives and the desire to maintain their membership in the organization. Thus, high employee engagement means favoring certain work of an individual, while a high organizational commitment means siding with the organization that recruited individuals (Robbins and Judge, 2008: 101).

Turnover is the entry and exit of workers in a company within a certain time (Flippo, 1994 in Rodly 2012: 8). When a hospital employee turnover level rise than previously, it is an indication of the decline in motivation, spirit, and morale. Additionally, it will reduce the productivity that can also lead to the continuity of the course of a hospital and the number of expenses incurred during the process of recruitment, training, to the placement. (Gray et al, 1996 in Rodly 2012: 8).
Mobley (2011: 121) states that the factors that predispose a person to move is determined by individual factors, including (1) Satisfaction of a job, this satisfaction can be conceptualized as a mismatch between what is valued by the individual with what is provided by the situation.

Turnover Intention is the attitude of workers in the form of a tendency to change jobs. Many factors can cause Turnover Intention, one of which is the job satisfaction experienced during the work in the working environment during the Multi Jaya Lombok. In this study the factors that may affect turnover Intentiondibatasi on Job Satisfaction, because it is believed the most influential in issues related to work conditions at the Multi Jaya Lombok.

Meanwhile, Job Satisfaction is the attitude of the employees who reflect dissatisfaction in the running for this job. Job satisfaction reflects satisfaction against the boss (supervision), a good boss means want to appreciate the work of subordinates. For subordinates, superiors can be regarded as a father/mother/friend and once his boss. Satisfaction with salary/wages (pay), is an employee of subsistence factors deemed appropriate or not. Satisfaction with the Promotion (promotion) is a factor related to whether there is an opportunity to gain career advancement during the work. Satisfaction with Coworkers (co-workers), is a factor related to the relationship between the employer and the employee to another employee, either the same or a different type of work.

Organizational commitment is the attitude of the members of the company so that it becomes an organizational culture because almost all the members are determined to have the commitment of the organization, so that can be described in the following models

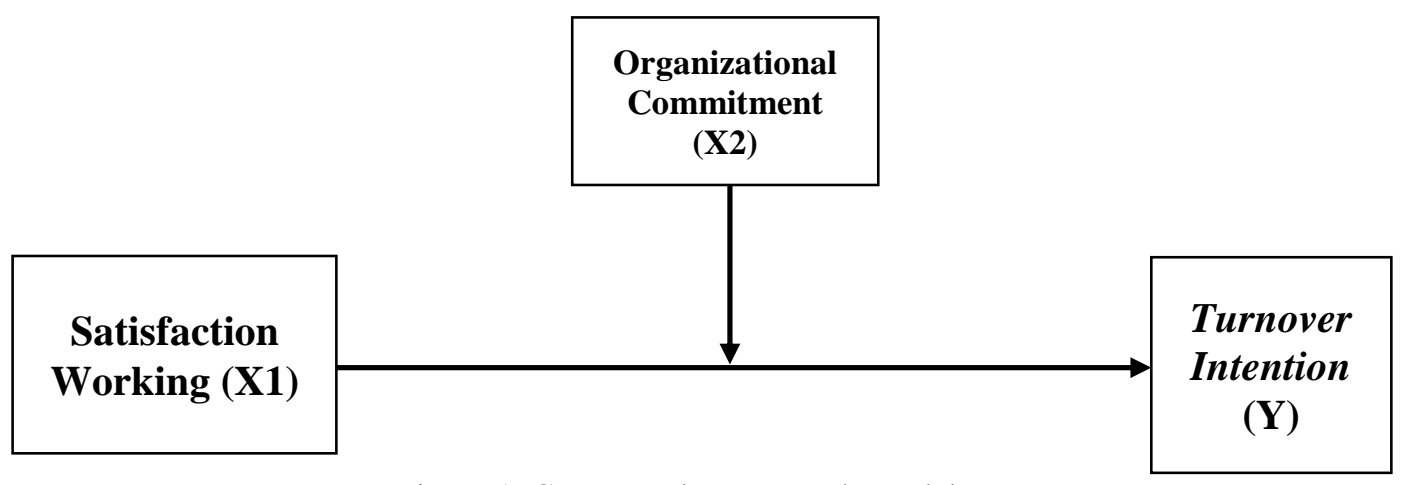

Figure 1. Conceptual Framework Model

Based on the above review, the research hypothesis can be formulated as follows:

1) H1: Job Satisfaction suspected positive effect on Turnover Intention in Multi Jaya Lombok.

2) H2: Allegedly organizational commitment to strengthen the influence of job satisfaction on employee turnover intention on Multi Jaya Lombok.

\section{RESEARCH METHODS}

In accordance with the formulation of the problem and the objectives to be done, the type of research used in this research is causal. "Causal research is research that aims to determine the relationship between two or more variables". (Sugiyono, 2010). This causal research will be 
able to show the form of the influence of the independent variables on the dependent variable in this study is organizational Commitment Low Job Satisfaction In Effect Against Multi Jaya Turnover Intention In Lombok, The population of this research is all employees some 115 people.

Data collection tools that will be used are a questionnaire, which is a list of questions/statements which are logically related to the research problem, and each question/statement is an answer that has meaning in testing hypotheses (Nazir, 2005). Data analysis techniques used in analyzing the influence of the independent variable on the dependent variable is moderating regression analysis (MRA). Moderated Regression Analysis (MRA) or test interaction is a special application of multiple linear regression in the regression equation which contains elements of interaction (multiplication of two or more independent variables) (Sugiyono, 2011: 120).

\section{RESEARCH RESULT}

Moderating Regression Analysis in the processing of Analysis (MRA) in this case using methods backward elimination of 1 (one) step model with the final result of the model as follows:

$$
\mathrm{Y}=\alpha+\beta 1 X 1+\beta 2 X 1 * X 2
$$

\section{$Y=3,531-0,253 X 1-0,421 X 1 * X 2$}

After constant $(\alpha)$ and other variables were not significantly dumped then:

$$
Y=-0,365 X 1-0,516 X 1 * X 2
$$

After analyzing the two models mentioned above, it can be said that this model is the best because it has a significance level (error rate) is no more / less than 0.05 $(5 \%)$ with a confidence level of $0.95(95 \%)$. As the second model, the variable that significantly influences the turnover intention consisted of Job Satisfaction (X1), Job Satisfaction * Commitment $(\mathrm{X} 1 * \mathrm{X} 2)$.

Based on empirical hypotheses have been proposed, then be lowered into a statistical hypothesis $\mathrm{H} 0$ : sig> 0.05 ; Ha: sig <0.05 level of significance was set at $5 \%$ $(0.05)$, or with a $95 \%$ confidence level. If the significance is smaller than the standard error $(5 \%)$ then the alternative hypothesis (Ha) is accepted it means there is a significant influence of the independent variable on the dependent variable. While the significance If greater than the standard error $(5 \%)$ then the null hypothesis (Ho) is received it means there is no significant influence of the independent variable on the dependent variable. The results of hypothesis testing can be seen in the table below.

Table 1. Significance of Moderating Regression Analysis

\begin{tabular}{lccc}
\hline \multicolumn{1}{c}{ Independent variables } & B & T & Sig. \\
\hline Job satisfaction & $-0,253$ & 4.795 & 0,000 \\
Job satisfaction * Commitment & -0.421 & 5.833 & 0,000 \\
\hline Dependent Variable: Turmover Intention
\end{tabular}

Dependent Variable: Turnover Intention

Based on the results of the empirical evidence on the Effect of Job Satisfaction and Organizational Commitment Against Turnover Intention in Lombok Multijaya shown in the tables above show that job satisfaction is a direct significant effect on Turnover Intention. Job satisfaction can also significantly influence turnover Intention when reinforced by Employee commitment.

\section{INTERPRETATION OF RESULTS}

Mobley Rodly (2012:17) states that many factors that cause employees to move from the workplace, but the factors that can influence the desire to move is job satisfaction. At the individual level, satisfaction is a psychological variable most commonly examined in a model of intention to leave. Aspects of satisfaction were found associated with the individual's desire to leave the organization includes the satisfaction of wages and promotion, supervision received satisfaction, satisfaction with co-workers and the satisfaction of a job and work contents.

Apart from that, Factors that may affect turnover intentions are the commitment of the organization. Because the relationship of job satisfaction and desire leave workplace variant explains only a small part then clearly the process models intention to leave the employee must use other variables beyond job satisfaction as the sole explanatory variables. Subsequent developments in the study of intention to leave insert the construct of organizational commitment as a concept that also describes the process as a form of behavior, organizational commitment can be distinguished from job satisfaction. Commitment refers to the emotional response (affective) individual to the entire organization, while satisfaction leads to emotional responses on specific aspects of the job.

So that could conclude that the intention to move (turnover intention) can be influenced by organizational 
ISSN 2201-2796

commitment and job satisfaction. According to Griffet (1995) in Rodley (2012: 19) that almost all models intention to leave because of the level of job satisfaction and organizational commitment is low.

The results of this study together with the results of research conducted by the Son (2016) conducting research The results showed that: (1) Job satisfaction is a significant negative effect on turnover intention (2) organizational commitment and significant negative effect on turnover intention (3) job satisfaction and organizational commitment jointly provide negative and significant impact on turnover intention

Prisca (2016) conducting research with outcome research that: (1) job satisfaction significant negative effect on employee turnover intention; (2) organizational commitment and significant negative effect on employee turnover intention; (3) job satisfaction and organizational commitment and significant negative effect on employee turnover intention.

Son et al (2015) conduct research outcome studies show that job satisfaction and organizational commitment simultaneously significant effect the intensity of the turnover. Second, that job satisfaction is significant negative effect on the intensity of turnover. Third, organizational commitment and a significant negative effect on the intensity of turnover.

Noviani (2017) conducting research with results that the truth of organizational commitment, job satisfaction, And organizational culture influence on turnover intention in Mutiara Merdeka Hotel Pekanbaru, organizational commitment take effect the intentions turnover at Mutiara Merdeka Hotel Pekanbaru, job satisfaction influence on turnover intention at Mutiara Merdeka Hotel Pekanbaru, organizational culture influence on turnover intention at Mutiara Merdeka Hotel Pekanbaru.

Ananda et al (2017) conducted a research study showing that (1) Job satisfaction and a significant negative effect on employee turnover intention. (2) organizational commitment and a significant negative effect on employee turnover intention.

\section{CONCLUSION}

Based on data analysis and discussion that has been done, it can be concluded that:

1) Directly, job satisfaction has a significant influence on Turnover Intention.

2) Employee commitment can strengthen the influence of Job Satisfaction on Turnover Intention.

\section{RECOMMENDATION}

From the study and the conclusions above, the things that can be suggested as follows.
1) To improve employee commitment, it is expected Parties management needs to pay attention to job satisfaction, especially in terms of their work.

2) It is expected that the management creates conditions conducive working environment so that it can build employee satisfaction,

3) To researchers who want to do further research on this issue, the authors expect the independent variables need to be propagated that allows increasing the significance of the influence of the independent variable on the dependent variable. In addition, this study can be used as a reference in the study.

\section{REFERENCES}

Abouraia, M., \& Othman, S. (2017). Transformational Leadership, Job Satisfaction, Organizational Commitment, and Turnover Intentions: The Direct Effects among Bank Representatives. American Journal of Industrial and, 7, 404-423.

Ananda, Tya Rahmah., Sukisno S. Riadi., And Syaharuddin Y., (2017), Effect of job satisfaction and organizational commitment to turnover intention, ECONOMIC FORUM Volume 19 (2), 2017, Faculty of Economics and Business, University of Mulawarman, Samarinda available on http://journal.feb.unmul.ac.id/index.php/forumekon omi,

Brown, ME, Trevino, LK, Harrison, DA, 2005. Ethical leadership: a social learning perspective for construct development and testing. Organizational Behavior and Human Decision Processes 97, 117134.

Gibson, JL, Ivancevich, JM, and Donnelly, JH, 2008, Organizational Behavior, Structure, and Process, Jakarta: Binapura Script Publisher.

Hasibuan, MSP, (2010), Human Resource Management Revised Edition, Jakarta: PT. Earth Literacy.

Handoko, TH, (2011), Personnel and Human Resources Management, 2nd Edition, Yogyakarta: Gadjah Mada University.

Ivancevich, JM, Robert, K., and Michael, TM 2008, Behavior and Management, Translate, Jakarta: Erland

Luthans, F. S (2005) Organizational Behavior, 10th Edition. Yogyakarta: Andi 
Mangkunagara, Anwar Prabu, 2011, "Human Resource Management Company", Bandung: PT. Youth Rosdakarya.

Mas'ud, F., (2009), Survey of Organizational Diagnosis Concepts and Applications, Master of Management, University of Diponegoro, Semarang: Diponegoro University.

Mobley, WH (2011). Turnover: Cause and Effect and control them. Jakarta: PT. Reader Binaman Pressindo.

Mondy, RW, 2008, Human Resource Management, Volume 2 Issue 10, Jakarta: PT. Primary Literacy surge.

Munandar, Asr Sunyoto. (2012). Industrial and Organizational Psychology. Jakarta: UI Press.

Nazir Muhammad. (2005). Research methods. Bandung: Youth Rosdakarya.

Noviani, Annisa Rachmah., (2017), Influence of Organizational Commitment, Job Satisfaction and Turnover Intention Of Organizational Culture On Merdekapekanbaru Mutiara Hotel Employee, Faculty Of Economic Riau University, Pekanbaru, Indonesia, Fekon JOM, Vol. 4. 1 (February) 2017, p 60-71.

Nugroho, Bhuono Court. (2011). Choosing Strategies Strategy Research Methods with SPSS Statistics. Yogyakarta: ANDI OFFSET

Pramesti Goddess and Mubasysyir Hasanbasri (2007). "Job Satisfaction, Organizational Commitment, and Desire to Quit in Purwokerto STIKES Harapan Bangsa". Working Paper Series, 7.

Prischa, Vidya Alfresia, (2016), Effect of Job Satisfaction and Organizational Commitment Against Employee Turnover Intention Study at PT. Kajima Indonesia), Abstract, Management Studies Program, Department of Management, Faculty of Economics, University of Yogyakarta.

Son, Ida Bagus Widyantara and Komang Ardana, (2015), Effect of Job Satisfaction and Organizational Commitment Against Employee Turnover intensity, E-Journal of Management Udayana
University, Vol. 4, No. 6, 2015: 1670-1683 ISSN: 2302-8912Faculty of Economics and Business, University of Udayana (Udayana), Bali, Indonesia,

Son, Nanda Nugrahena., (2016), Effect of Job Satisfaction and Organizational Commitment Against Nurse Turnover Intention Klampok Emanuel Hospital, Abstract, Program Management StudiesDepartment of Management, Faculty of Economics, University of Yogyakarta.

Ridlo, Ilham Aksanu. (2012). Employee Turn Over "Literature". Surabaya: PH Movement Publication.

Rival, V. (2004). Management of Human Resources for the Company from Theory to Practice. : PT RajaGrafindo Persada.

Robbins, Stephen, and Timothy A., Judge, 2008, "Organizational Behavior, Organizational Behavior", Book Translation, Jakarta: Gramedia.

Silalahi, Uber, 2010, Methods of Social Research. Bandung: PT Refika Aditama

Sri Kuntjoro, Zainuddin. 2002. Organizational Commitment. Downloaded from www.ePsikologi.com

Sugiyono. (2010). Methods Administrators. Bandung: Alfabeta.

Sunyoto, Asr Munandar, 2001, the Industrial and Organizational Psychology, Jakarta: The University of Indonesia (UI-Press).

Kelvin \& Indriantoro, N. (1999) Turnover Model Pasewark \& Strawser: Empirical Study on Environmental Public Accountant. Riser Journal of Accounting Indonesia, 2. 173-195

Usman and Akbar (2008), Methods of Social Research. Jakarta: Earth Literacy.

Widodo, Rohadi. (2010). Analysis of Effect of Occupational Safety and Organizational Commitment on Turnover Intention and Impact on Employee Outsourcing. Thesis. Semarang: Diponegoro University. 